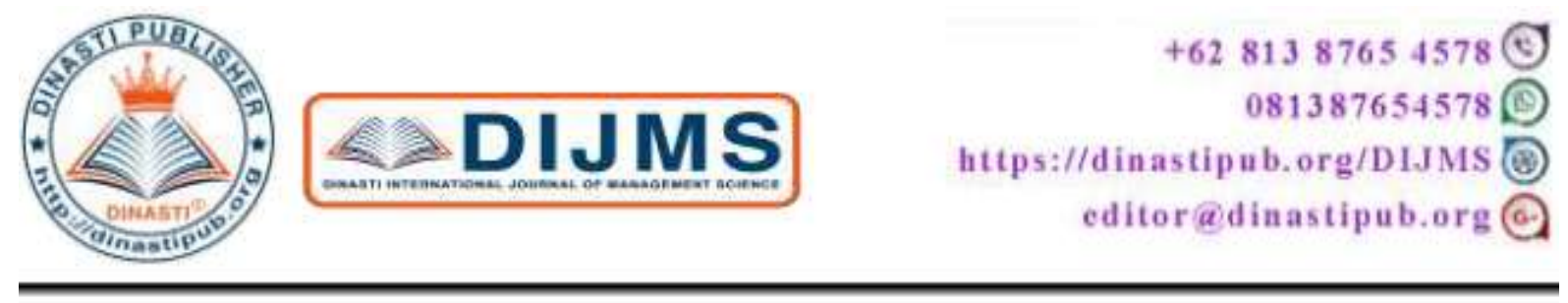

\title{
EFFECT OF IHSG, MONEY ALLOCATED, AND IMPORT VALUE ON VAT RECEIPT IN INDONESIA
}

Suparna Wijaya ${ }^{1}$, Utari Ayu Surinawa ${ }^{2}$, Waidatin Nur Azizah ${ }^{3}$

${ }^{1,2,3)}$ Politeknik Keuangan Negara STAN, Indonesia

\begin{tabular}{|l|l|}
\hline ARTICLE INFORMATION & $\begin{array}{l}\text { Abstract: Value Added Tax has a role that is quite large } \\
\text { Received: 10 March 2020 } \\
\text { in state revenue. And the Composite Stock Price Index } \\
\text { Issued: 27 March 2020 } \\
\text { (IHSG) is a reflection of stock performance or good } \\
\text { financial performance. If financial performance is good, } \\
\text { sales and VAT will increase. Money supply reflects } \\
\text { Suparna Wijaya }\end{array}$ \\
$\begin{array}{l}\text { E-mail: } \\
\text { level of domestic consumption, if money supply rises, } \\
\text { level of consumption increases, VAT will growth. } \\
\text { Import value is a reflection of the import itself. If } \\
\text { imports increase, the supply of goods from abroad to the } \\
\text { country increases. If supply increases, consumption also } \\
\text { increase, so VAT will grow. The purpose of this study } \\
\text { was to examine the effect of IHSG, Money Supply, and } \\
\text { Import Value on VAT receipts. The research method } \\
\text { used is quantitative. The results showed that IHSG did } \\
\text { not affect VAT receipts. Whereas Money Supply and } \\
\text { Import Value have a significant influence on VAT } \\
\text { receipts. However, IHSG, Money Supply, and Import } \\
\text { Value simultaneously influence VAT revenue. } \\
\text { Keywords: Value Added Tax, Consumption Tax, Cspi, } \\
\text { Don:10.31933/DIJMS }\end{array}$ \\
\hline
\end{tabular}

\section{INTRODUCTION}

Indonesia is a country that is actively building. This makes more budget allocated for development. In this process, of course, it has an impact on the increasing need for funds that must be spent by the government. The most potential source of government revenue is tax, which is around $85.6 \%$ of the total revenue of the State Budget (APBN). In the Financial Note along with the 2017 State Budget for the 2017 fiscal year, Value Added Tax (VAT) has a significant role in state revenue, which is second only to the Income Tax.

In the past 4 years, VAT receipts have increased. This can be seen in the graph below. 


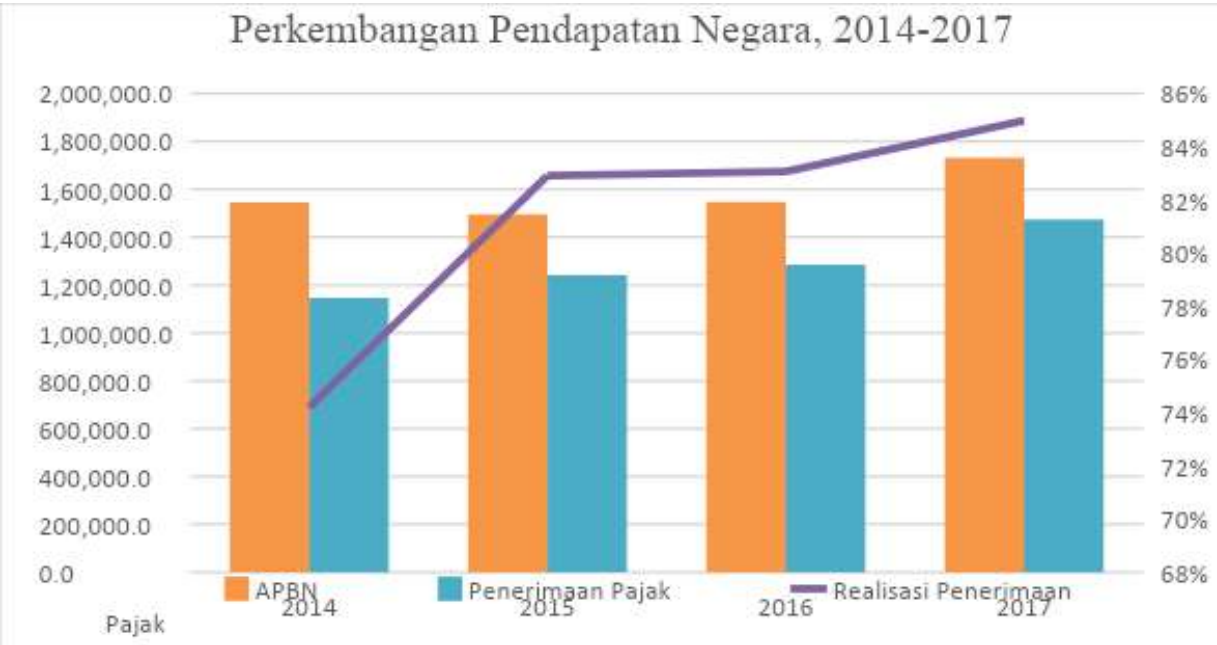

Figure 1. The graph on Development of State Revenues, 2014-2017

Source: Ministry of Finance

In the national economy, the term Gross Domestic Product (GDP) is known. Mankiw (2006) states that GDP is the market value of all final goods and services produced by a country in a certain period. GDP is the value used to measure a country's economy.

The high GDP growth rate reflects the country's increasing level of prosperity. An increase in GDP means an increase in people's purchasing power, an increase in people's purchasing power increasing VAT revenue because VAT is a tax on consumption.

GDP has several components consisting of consumption, investment, government spending, and net exports. Of the several components, each influences how much VAT the government can receive. This research will discuss the derivative of some of these components namely the Composite Stock Price Index (CSPI), money supply, and import value, each of which represents an investment, consumption, and part of net exports. Then all of that is associated with VAT, which is a component of government spending.

Speaking of investments, an investor will invest in stocks by reading which stock potentials are good for him to buy. This can be illustrated from the CSPI issued by the Indonesia Stock Exchange every working day. The understanding of the CSPI itself is a value used to measure the combined performance of all shares listed on the stock exchange. The purpose of the combination of all shares is the performance of shares included in the calculation of all shares listed on the stock exchange (Sunariyah, 2006). JCI is one indicator of a company's economic growth.

Good CSPI is caused by good stock performance. This is in line with company performance which can be seen or measured through financial performance. If a company's financial performance is good, the company will benefit. This is associated with the increasing number of sales that occur. If sales increase, VAT increases.

To see the company's performance, fundamental analysis can be done. Perdana (2016) in Corrado (2002), "examination of a firm's accounting statement and other financial and economic information to assess the stock". Fundamental analysis is useful for examining a company's financial statements and calculating financial performance. Also, it is used to 
determine the valuation of stock prices and determine whether a stock that is on the market is currently overvalued or undervalued.

The second component is consumption. Consumption meant here is consumption carried out by the community. Indirect consumption can be seen from the money supply, that is, the amount of money available in the hands of the public. The law gives the government a monopoly on printing money. Circulation of money consists of a narrow meaning (M1) and broad meaning (M2), which is used in this paper is M2, hereinafter referred to as money supply.

The money supply is influenced by several factors, one of which is income. Revenue is the amount of money received by the community at a certain time. Thus, if the community's income rises, then the money that can be transacted or spent also increases. Keynes's theory of money supply states that the increase in the money supply has a positive effect on output and economic growth. Because with the increase in the money supply it is expected that the level of public consumption will increase thereby encouraging economic growth. So it can be said that the money supply is closely related to consumption.

The third component represents net exports, namely the value of imports. In article 1 number 20 of Law No. 42 of 2009 concerning Value Added Tax of Goods and Services and Sales Tax on Luxury Goods, which is called import value, is the value in the form of money which is the basis for calculating import duties plus levies based on the provisions in the legislation governing customs and excise for the import of Affected Goods Taxes, not including Value Added Tax and Sales Tax on Luxury Goods.

Apart from the three components above, another component of GDP is government spending. Government spending can be done when the government has funds which when associated with the APBN posture are referred to as state revenue. As stated above, the largest component of state revenue is tax revenue, one of which is VAT. A VAT is a tax that is very closely related to the three previous components. The objective to be achieved with this research is to examine the effect of CSPI, money supply, import value on VAT.

In this study the authors limit each of the variables tested, namely IHSG, money supply, import value, and VAT in the form of time series with a period of January 2014 to December 2016, amounting to 36 observations. Data comes from the Indonesia Stock Exchange, Bank Indonesia, the Central Statistics Agency, and the Directorate General of Taxes.

\section{LITERATURE REVIEW}

\section{Value Added Tax}

Imports the purchase and entry of goods into a customs area. Nuzula, Sedyaningrum, and Suhadak (2006) in Murni (2009) stated that import is an economic activity to buy foreign products for domestic needs or markets. The tendency of large import activities is not entirely bad for a country because imports will also stimulate investment activities if imported goods are capital goods, raw goods, or semi-finished goods for industrial purposes. For import events, there is an import value which is the basis for calculating import duties. Import duty is a state levy imposed on imported goods. 


\section{Macroeconomics}

A country's economic growth illustrates the increase in living standards over time that comes from an increase in income, thus allowing people to consume more and more varied goods and services (Mankiw, 2003). To measure economic growth, economists use the Gross Domestic Product data.

To look at GDP statistics there are two ways, namely; (1) GDP as the total income of each person in the economy, (2) GDP as total expenditure on the economic output of goods and services. So, from the second perspective, it is clear that GDP is a reflection of economic performance.

The components of GDP in the national income accounts are divided into four expenditure groups, namely consumption, investment, government spending, and net exports. Consumption consists of goods and services purchased from households, investments consisting of goods purchased for future use, government purchases are goods and services purchased by the central and regional governments, and net exports represent the value of goods and services exported to other countries minus the value of goods and services imported from other countries.

One method used in calculating GDP is the expenditure approach (expenditure approach). According to the method of spending, there are several types of aggregate expenditure in an economy:

Consumption of Households(HouseholdConsumption)

$\square$ Government consumption(GovernmentConsumption)

$\square$ Expenditure Investments(InvestmentExpenditure)

$\square$ Net Exports(NetExport)

so that the GDP can be calculated using the formula:

$\mathrm{PDB}=\mathrm{C}+\mathrm{G}+\mathrm{I}+(\mathrm{X}-\mathrm{M})$

Where: $\mathrm{C}=$ household consumption;

$\mathrm{G}=$ government consumption;

$\mathrm{I}=$ investment;

$\mathrm{X}=$ export;

$\mathrm{M}=$ import

\section{JCI}

The stock price index is a price index that measures changes in stock prices in the capital market. By looking at the development of the stock price index, stock market players can make the right decisions in the stock trading activity. In the stock price index, there is one composite Stock Price Index (CSPI). JCI is a value used to measure the combined performance of all shares listed on the stock exchange by being influenced by the market capitalization of a stock.

Indeks $=\frac{\sum(P X Q)}{N d} \times 100$

$\mathrm{P}$ is the share price on the regular market. $\mathrm{Q}$ is the weight or number of each stock. $\mathrm{Nd}$ is the basic value, that is the value formed based on the number of shares listed at a time. 


\section{Money Supply}

The definition of money supply can be divided into two meanings, namely understanding in the narrow sense and understanding in the broad sense. (Damayanti 2010 in Asfia Murni. 2006)

1. Circulation of money in the narrow sense (M1), is the amount of money in circulation that is often used for transaction purposes, consisting of:

- coins/coins and banknotes commonly called currency;

- demand deposits or bank money, i.e. deposits held at commercial banks and can be issued by check.

$\mathrm{M}_{1}=\mathrm{C}+\mathrm{DD}$

Where: $\mathrm{M}_{1}=$ money in the narrow sense

$\mathrm{C}=$ currency, currency

DD = Demand deposit, demand deposits

2. Circular money in the broad sense (M2), i.e. M1 (coins, banknotes, and demand deposits/checks) plus money quasi. Quasi money is savings and other wealth accounts that can be exchanged/disbursed soon. The money supply is stated as follows.

$\mathrm{M} 2=\mathrm{M} 1+$ Uang kuasi

$\mathrm{M}_{2}=\mathrm{M}_{1}+\mathrm{TD}+\mathrm{SD}$

Where: $\quad \mathrm{M}_{2}=$ money in the broad sense

$\mathrm{M}_{1}=$ money in the narrow sense

$\mathrm{TD}=$ time deposits (deposits)

$\mathrm{SD}=$ saving deposits (savings balance)

\section{Value of Imports}

Imports the purchase and importation of goods into the customs area. Nuzula, Sedyaningrum, and Suhadak (2006) in Murni (2009) stated that import is an economic activity to buy foreign products for domestic needs or markets. The tendency of large import activities is not entirely bad for a country because imports will also stimulate investment activities if imported goods are capital goods, raw goods, or semi-finished goods for industrial purposes. For import events, there is an import value which is the basis for calculating import duties. Import duty is a state levy imposed on imported goods. ${ }^{1}$

Import value can be calculated by the formula:

Value import $=\mathrm{CIF}+$ import duty + other tax

CIF (Cost Insurance and Freight), cost means the price of the item, insurance means insurance attached to the goods, and freight means shipping costs. Freight that is often used is freight on board (FOB), meaning that the exporter is only responsible until the goods are on the vessel (vessel).

To calculate the import duty, a rate of exchange prevailing at that time is required, the rate is set weekly by the Minister of Finance. The import duty on an item has also been determined in the Indonesian Customs Tariff Book (BTKI).

\footnotetext{
${ }^{1}$ www. beacukai.go.id
} 


\section{Previous Research}

Mulyadi (2011) explained that household, private consumption, and government spending had a positive and significant effect on VAT revenue. While the value of imports has a negative and significant impact on VAT receipts.

\section{Hypothesis}

Based on the theoretical basis and previous research, the hypotheses that will be used in this study are:

H1: CSPI affects the acceptance of VAT

H2: Money Supply influences the acceptance of VAT

H3: Import Value influences the acceptance of VAT

\section{RESEARCH METHODS}

In writing this paper the author uses a quantitative method. According to Sugiyono (2013), quantitative methods are used to examine populations or specific samples, sampling techniques are generally carried out randomly, data collection uses research instruments, data analysis is quantitative/statistical to test the hypotheses that have been set.

The approach used is a descriptive approach to describe the research object or research results. The descriptive notion according to Sugiyono (2012) is a method that serves to describe or give an overview of the object under study through data or samples that have been collected as they are, without conducting analysis and making generally accepted conclusions. The data source used in this study is secondary data. Secondary data is a source of research data obtained indirectly through intermediary media, obtained and recorded by other parties (Sugiyono, 2014).

\section{FINDINGS AND DISCUSSION}

\section{Estimation of Multiple Linear Regression}

The results of the estimation of the multiple linear regression model are as follows:

Figure III. 1

Estimation Results of Multiple Linear Regression Model

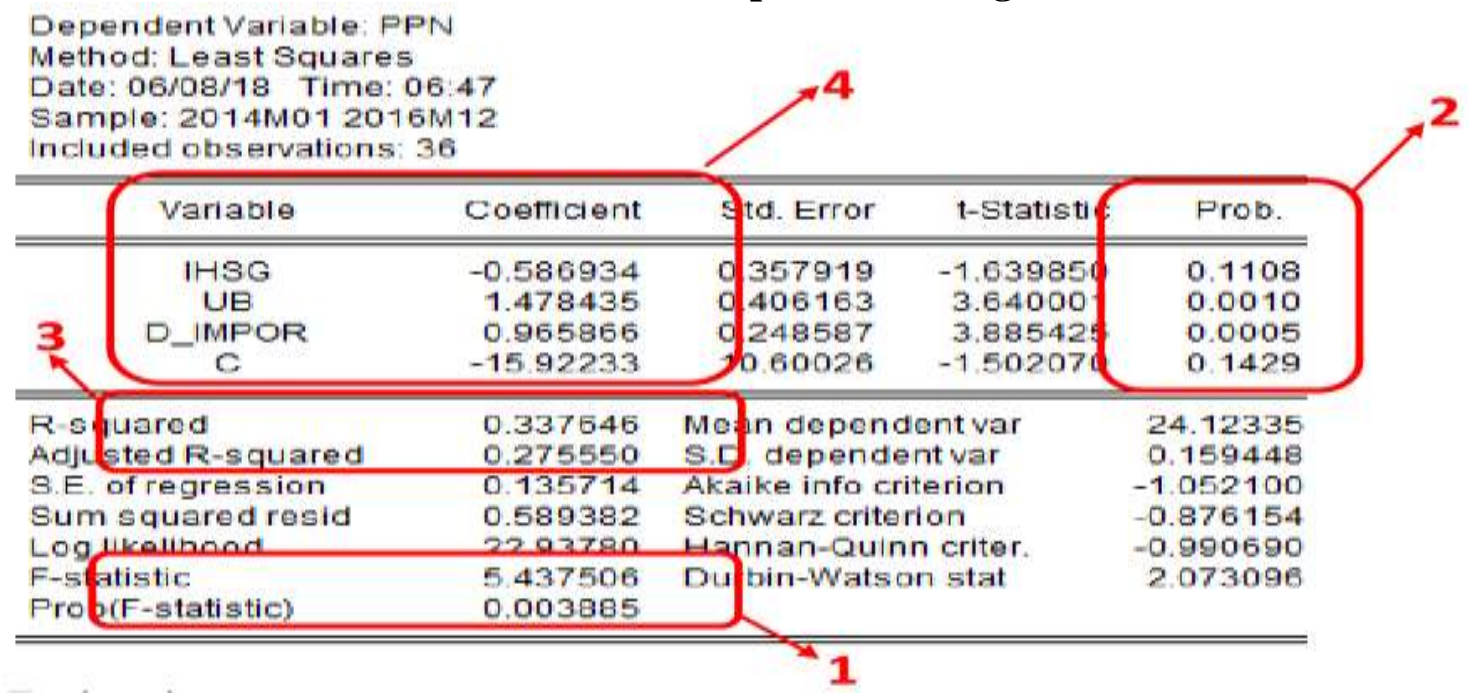




\section{Explanation:}

1. F Test (Simultaneous)

The $\mathrm{F}$ Test results can be seen in point 1 namely $F$-statistic and prob ( $f$ statistic). The F-statistics are compared with the $\mathrm{F}_{\text {-Table }}($ found in Table F).

The conclusions generated in this $\mathrm{F}$ test are as follows:

- $\mathrm{F}_{\text {arithmetic }}>\mathrm{F}_{\text {table }}$ then $\mathrm{H}_{0}$ is rejected and $\mathrm{H}_{1}$ fails to reject, meaning that all independent variables together constitute a significant explanation of the dependent variable.

- $\mathrm{F}_{\text {arithmetic }}<\mathrm{F}_{\text {table }}$ then $\mathrm{H}_{0}$ fails to reject and $\mathrm{H}_{1}$ is rejected, meaning that all independent variables together do not constitute a significant explanation of the dependent variable.

In the above results obtained $\mathrm{F}_{\text {count }}=5.43$, while according to table $\mathrm{F}, \mathrm{F}_{\text {table }}=$ 2.90. By the conclusions in the $F$ test if $F_{\text {arithmetic }}>F_{\text {table }}$ then $\mathrm{H}_{0}$ is rejected and $\mathrm{H}_{1}$ fails to reject, meaning that all independent variables simultaneously are significant explanations of the dependent variable. $\mathrm{F}_{\text {arithmetic }}>\mathrm{F}_{\text {-table }}$, i.e. $5.43>2.90$. With a $95 \%$ confidence level, it can be concluded that CSPI, money supply and import value simultaneously have a significant effect on VAT.

When using a probe ( $f$-statistics), the results are compared with the significance level or $\alpha . \alpha$ was determined by researchers, generally $5 \%(0.05)$. In the data above, the F-statistic $<\alpha$ is $0.003885<0.05$. Thus, $\mathrm{H}_{0}$ is rejected and $\mathrm{H}_{1}$ failed rejected, meaning that the stock index, money supply, and the import value simultaneously significant effect on VAT.

2. The T-Test (Partial)

The results of the t-test can be seen in point 2, namely T-StatisticandProb. The conclusions that can be taken in this test are as follows:

- If $\mathrm{T}_{\mathrm{T}}$ arithmetic $<_{\mathrm{T} \text { table }}$ then $\mathrm{H}_{0}$ fails to reject and $\mathrm{H}_{1}$ is rejected, meaning that there is no significant effect between the independent variables on the dependent variable.

- If ${ }_{\mathrm{T}}$ arithmetic $>\mathrm{T}_{\text {table }}$ then $\mathrm{H}_{1}$ fails to reject and $\mathrm{H}_{0}$ is rejected, meaning that there is a significant influence between the independent variables on the dependent variable.

If using $t$-Statistic, compare the $t$-Statistic with $\mathrm{T}$ table (obtained from Table $\mathrm{T}$ ). As discussed above, decision-making t-Statistic is that if $\mathrm{t}_{\text {arithmetic }}<\mathrm{t}_{\text {table }}$ then $\mathrm{H}_{0}$ fails to reject and $\mathrm{H}_{1}$ is rejected, whereas if $t_{\text {arithmetic }}>\mathrm{T}$ table then $\mathrm{H}_{0}$ is rejected and $\mathrm{H}_{1}$ fails to reject.

If usingProb. then compare with a significance level or $\alpha$. In the data above, first, an analysis is made on the JCI variable, Prob. $>$ A is 0:11>0.05 then H0 fails to reject and $\mathrm{H}_{1}$ rejected, meaning that the variable JCI no significant effect on VAT. Second, analysis of the money supply variable, Prob. $<$ A yatu $0.001<0.05$ then $_{\mathrm{HO}}$ is rejected and $\mathrm{H}_{1}$ failed rejected, meaning that the variable significant effect on the money supply VAT. Third, an analysis of the import value variable, Prob. $<\alpha$ namely 
$0.0005<0.05$ then $\mathrm{H}_{0}$ is rejected and $\mathrm{H}_{1}$ fails to reject, meaning that the variable value of imports also has a significant effect on VAT.

a. Determinant Coefficient

Results Test of the coefficient of determination can be seen atpoint3, namelysquare, and adjusted R-squared. The use of adjusted R-squared is done if the regression model has been modified in the study such as the addition and/or reduction of independent variables.

In this study, the regression model no increase and/or reduction of independent variables that are used to test the $R$-squared $\left(R^{2) .}\right.$ The value of $R^{2}$ of 0.337646 , meaning that variations of all independent variables (JCI, money supply and the value of imports) can influence the dependent variable (VAT) amounted to $33.76 \%$ (0.337646), while the remaining $66.23 \%(0.662354)$ is influenced by other variables outside the research.

b. Linear Regression Model

The final stage is to construct a linear regression equation model. The results of the regression model can be seen as inpoint4. Value in the Column Coefficient Variable JCI, UB and D_IMPOR in a row is the value of $\beta 1, \beta 2$, and $\beta 3$, while the variable $\mathrm{C}$ (constant) is the value of $\alpha$. So that the regression equation in this study can be arranged as follows: The

$\ln (P P N)=-15.92233-0.586934 \ln ($ IHSG $)+1.478435 \ln ($ UB $)+0.965866 \ln ($ D_IMPOR $)$

Interpretation of the regression equation above is as follows:

- $\alpha=-15,92233$, meaning that if IHSG, UB and imports are 0, the VAT is $-15,92233$ but not significant at alpha of $5 \%$.

*) Note: In this data, JCI may not be very close to 0 or even negative even though it is in the form of natural logarithms. Because the natural logarithm of $1=0$ and below 1 $=$ is negative. If the JCI is very close to 0 , then it is certain that the Indonesian economy has plummeted. Thus, the value of constants in the regression model cannot be verified.

- $\beta 1=-0.586934$, meaning that with the assumption of money supply and fixed import value, any increase in CSPI by $1 \%$ will reduce VAT by $0.586934 \%$.

*) Note: The negative sign on $\beta 1$ is the direction of the JCI effect on VAT. In the data above, CSPI harms VAT but is not significant at an alpha of 5\%

- $\beta 2=1.478435$, meaning that with the assumption of JCI and fixed import data, each increase in money supply by $1 \%$ will increase VAT by $1.478435 \%$.

*) Note: A positive sign on $\beta 2$ indicates that the money supply has a positive effect on VAT and is significant at $\alpha=5 \%$. From the results of the multiple linear regression model, the circulation is the most influential variable on VAT.

- $\beta 3=0.965866$, meaning that assuming JCI and fixed money supply, each increase in import data by $1 \%$ will increase VAT by $0.965866 \%$.

*) Note: A positive sign at $\beta 3$ indicates that import data has a positive effect on VAT and is significant at $\alpha=5 \%$. 


\section{Classical Assumptions}

1. Testing Multicollinearity Test

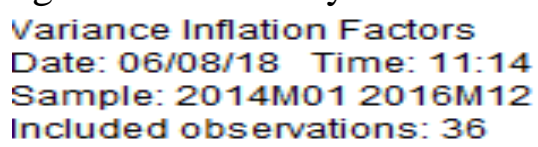

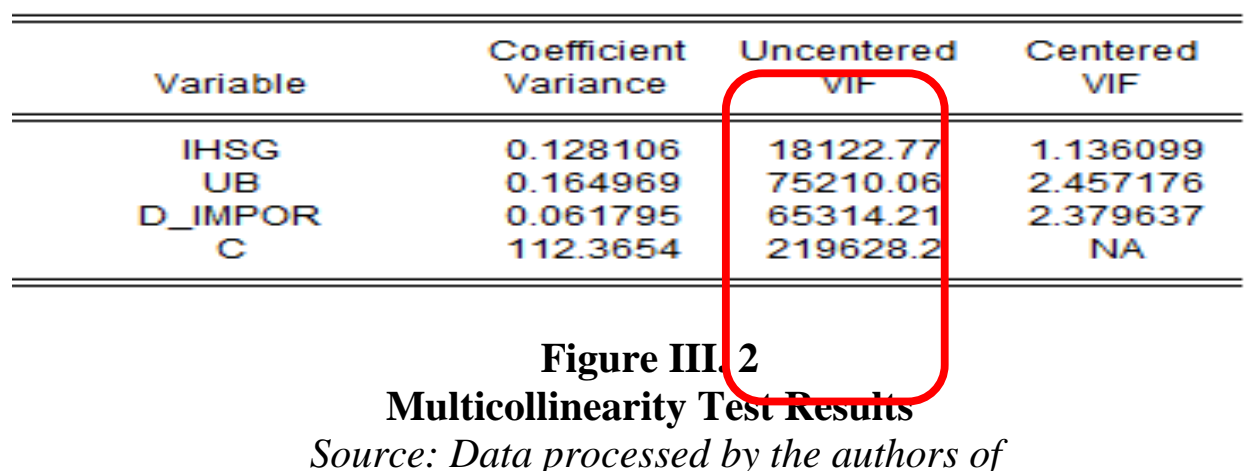

The multi collinearity test using VIF (Variance Inflation Factors). The VIF value of each variable does not exceed 5 , so it can be said that there is no multi collinearity in the three variables. That is, the regression model can be said either because there is no correlation between the independent variables.

2. Autocorrelation Test

\begin{tabular}{|lrll|}
\hline \multicolumn{4}{|l|}{ Preusch-Godfrey Serial Correlation LM lest: } \\
\hline \hline F-statistic & 0.121321 & Prob. F(2,30) & 0.8862 \\
Pbs*R-squared & 0.288835 & Prob. Chi-Square(2) & 0.8655 \\
\hline \hline
\end{tabular}

Figure III. 3

\section{Autocorrelation Test Results}

Source: Data processed by the author

The data used in this study is time-series data so that the assumption is required to be auto correlated. At the output $E$ views above, it can be seen the value of the $\mathrm{F}$ calculated probability is 0.8862 , the value of Prob F count is greater than 0.05 (alpha level used) so that its conclusion $\mathrm{H}_{0}$ fails to reject no autocorrelation.

3. Normality

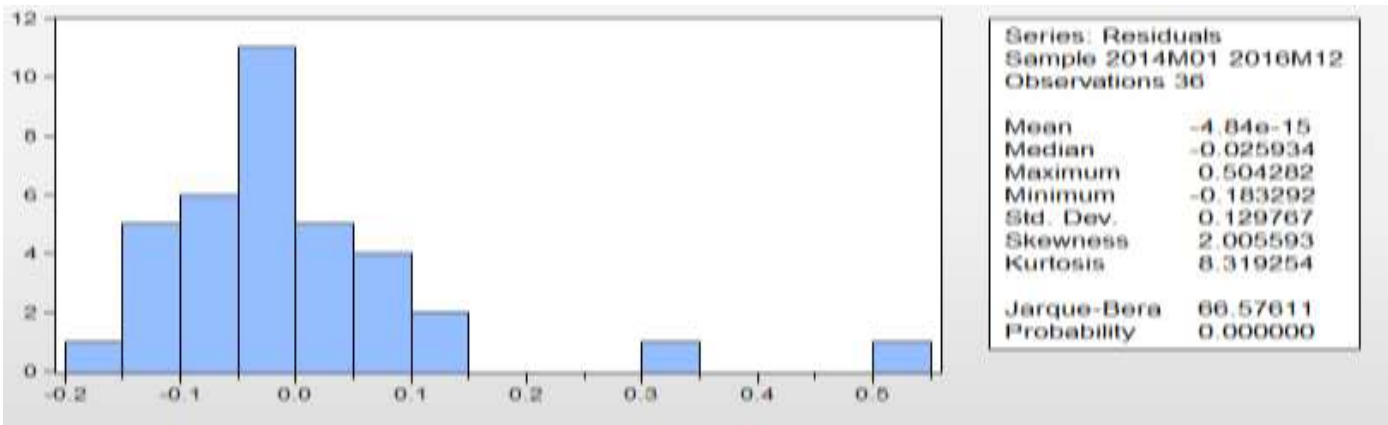

Figure III. 4

Normality Test Results

Source: Data processed by the author 
The normality test uses residual data that is formed in a normally distributed linear regression model. The method is to compare values Jarque-Bera with the alpha level used.

The conclusion that can be drawn from this test is if the probability value JarqueBera is greater than the alpha level used (0.05), it can be concluded that the residuals are normally distributed, and vice versa. From the research results obtained probability value Jarque-Bera of 66,576 , greater than 0.05 which concluded that the residuals were normally distributed.

4. Heteroscedasticity

Heteroscedasticity occurs when residuals and predictive values have correlations or relationship patterns. This relationship pattern is not only limited to linear relationships.

\begin{tabular}{|c|c|c|c|}
\hline Heteroskedasticity $\mathrm{Te}$ & lejser & & \\
\hline F-statistic & 1.189267 & Prob. $F(3,32)$ & 0.3294 \\
\hline Obs*R-squared & 3.611155 & Prob. Chi-Square(3) & 0.3066 \\
\hline Scaled explained SS & 4.900264 & Prob. Chi-Square(3) & 0.1792 \\
\hline
\end{tabular}

Figure III. 5

Heteroscedasticity Test Results

Source: Data processed by the author The

The decision of whether or not heteroscedasticity occurs in the linear regression model is to look at the Prob value. F-statistics (F arithmetic). If the value of Prob. F count larger than the alpha level of $0.05(5 \%)$ then $_{0}$ failed to reject meaning not happen heteroskedasticity, whereas if the value of Prob. F count is smaller than the alpha level of $0.05(5 \%)$ then $\mathrm{H}_{0}$ is rejected, which means going heteroskedasticity. Prob value. F count of 0.3294 is greater than the alpha level of $0.05(5 \%)$ so that based on the hypothesis test $\mathrm{H}_{0}$ is rejected, which means that there is no heteroscedasticity. All classic assumption tests in the log-linear model have been fulfilled so that the model is feasible to use to explain the effect of the JCI independent variable, money supply, and import value on VAT.

\section{CONCLUSION AND SUGESTION}

Through the t-test (partial) on the CSPI, the results of Prob. $>\mathrm{A}$ is $0: 11>0.05$ then $\mathrm{H}_{0}$ fail to reject and $\mathrm{H}_{1}$ rejected, meaning that the variable JCI no significant effect on VAT. Then based on the linear model equation obtained $\beta 1=-0.586934$, meaning that with the assumption of money supply and fixed import value, then any increase in CSPI by $1 \%$ will reduce VAT by $0.586934 \%$.

Through the t-test (partial) of the money supply, results are obtained Prob. $<$ A yatu $0.001<0.05$ then $_{\mathrm{H} 0}$ is rejected and $\mathrm{H}_{1}$ failed rejected, meaning that the variable significant effect on the money supply VAT. Then based on the linear model equation obtained $\beta 2=$ 1.478435 , meaning that with the assumption of JCI and fixed import data, each increase in money supply by $1 \%$ will increase VAT by $1.478435 \%$.

Through the t-test (partial) on the value of imports obtained results Prob. $<\alpha$ namely $0.0005<0.05$ then $\mathrm{H}_{0}$ is rejected and $\mathrm{H}_{1}$ fails to reject, meaning that the import value variable 
has a significant effect on VAT. Then based on the linear model equation obtained $\beta 3=$ 0.965866, meaning that assuming IHSG and fixed money supply, each increase in import value of $1 \%$ will increase VAT by $0.965866 \%$.

In the $\mathrm{F}$ test (simultaneous)results obtained $F$-statistic 5.43, greater than the $\mathrm{F}$ in the table is 2.90 and the Prob ( $F$-statistic) 0.003885 is smaller than the alpha determined at 0.05 . It can be concluded that all independent variables simultaneously constitute a significant explanation of the dependent variable, meaning that the CSPI, money supply, and the import value simultaneously have a significant effect on VAT. Then from test, the R-squared $\left(\mathrm{R}^{2)}\right.$ obtained a value of 0.337646 , meaning that all independent variables (JCI, money supply and the value of imports) can influence the dependent variable (VAT) amounted to $33.76 \%$ (0.337646), while the remaining $66.23 \%$ (0.662354 ) is influenced by other variables outside the study.

All classic assumption tests have been fulfilled. First, the multicollinearity test results do not occur multicollinearity, meaning that there is no correlation between the independent variables so that the regression model can be said to be good. Second, the autocorrelation test results do not occur autocorrelation because the calculated $\mathrm{F}$ value is greater than the alpha that is determined. Ie 0.06882> 0.05. Third, in the normality test, the residuals are drawn normally distributed because the probability value Jarque-Bora is greater than the determined alpha which is 66.576> 0.05. Finally, the heteroscedasticity test does not occur heteroscedasticity because the probability value is F-statistic greater than the alpha determined, which is $0.3294>0.005$.

\section{REFERENCE}

Anthanasius, Thomas. 2012. Panduan Berinvestasi saham (Updated). Jakarta: PTAlex Media Komputindo.

Anonim. Tanpa Tahun. Analisis Spillover Volatilitas Kurs USD-IDR dengan Indeks Harga Saham Gabungan (IHSG). Diakses dari repository.telkomuniversity.ac.idpustaka files127610bab1 analisis-spillover-volatilitas-kurs-usd-idr-dengan-indeks-hargasaham-ga bungan-ihsg-.pdf.

Anonim. Tanpa Tahun. BAB III: Metodologi Penelitian. Diakses dari abstrak.ta.uns.ac.idwisudauploadF0112063_bab3.pdf.

Damayanti, Safitri. Analisis Variabel Ekonomi yang Mempengaruhi Jumlah Uang Beredar di Indonesia. Jakarta: Universitas Islam Negeri Syarif Hidayatullah.

Damodar N., Gujarati dan Dawn C. Porter. 2013. Dasar-dasar Ekonometrika (Buku 2 Edisi 5). Raden Carlos Mangunsong (penj.). Jakarta: Salemba Empat.

Lestari, T.P.. 2016. BAB III: METODOLOGI PENELITIAN. Diakses dari etheses.uinmalang.ac.id1560711520066_Bab_3.pdf.

Iqbal, Muhammad. Tanpa Tahun. Pengolahan Data dengan Regresi Linier Berganda (dengan EViews).

Mankiw, N.Gregory. 2006. Principle of Economic:Pengantar Ekonomi Makro. Jakarta: Salemba Empat.

Mulyadi, M Syarif. 2011. Kontribusi, Efektifitas, Efisiensi, Dan Faktor-Faktor Yang Mempengaruhi Penerimaan Pajak Pertambahan Nilai. Jakarta : Kajian Ekonomi dan Keuangan (KEK) Badan Kebijakan Fiskal

Murni, Asfia. 2009. Ekonomika Makro. Bandung: PT Refika Aditama. 
Perdana, Diestra, Raden Rustam, dan Ari Darmawan. 2016. Analisis Fundamental dalam Penilaian Harga Saham dengan Menggunakan Metode Dividend Discounted Model dan Price Earning Ratio (Studi Pada Perusahaan Multinasional Sub Sektor Semen yang terdaftar di Bursa Efek Indonesia Periode 2013-2015): Jurnal Administrasi Bisnis (JAB)|Vol. 37 No. 2 Agustus 2016.

Republik Indonesia. 2009. Undang-undang Republik Indonesia Nomor 42 Tahun 2009 tentang Perubahan Ketiga Atas Undang-undang Nomor 8 Tahun 1983 Tentang Pajak Pertambahan Nilai Barang dan Jasa dan Pajak penjualan Atas Barang Mewah. Jakarta: Sekretariat Negara.

Sa'diyah, H.. 2014. BAB IV: GAMBARAN UMUM. Diakses dari repository.uinsuska.ac.id40655BAB\%20IV.pdf.

Sedyaningrum, Miranti, Suhadak, dan Nila Firdausi Nuzula. 2016. Pengaruh Jumlah Nilai Ekspor, Impor dan Pertumbuhan Ekonomi terhadap Nilai Tukar dan Daya Beli Masyarakat di Indonesia: Studi pada Bank Indonesia Periode Tahun 2006: IV2015:III. Jurnal Administrasi Bisnis (JAB), Vol. 34, No. 1: 114-121.

Suandy, Erly. 2002. Perpajakan. Jakarta: Salemba Empat.

Sudiyatno, Bambang dan Cahyani Nuswandhari. 2009. Peran Beberapa Indikator Ekonomi dalam Mempengaruhi Risiko Sistematis Perusahaan Manufaktur di Bursa Efek Indonesia Jakarta. Dinamika Keuangan dan Perbankan, Vol. 1, No. 2: 66-81.

Sugiyono. 2012. Metode Penelitian Kuantitatif Kualitatif dan R\&D. Bandung: Alfabeta.

Sukardji, Untung. 2015 . Pokok-pokok PPN:Pajak Pertambahan Nilai di Indonesia. Jakarta: Rajawali Pers.

Sunariyah. 2006. Pengantar Pengetahuan Pasar Modal. Yogyakarta. UPP STIM YKPN.

Utari, Woro. 2008. Analisis Fundamental Ekonomi Makro serta Pengaruhnya terhadap Penerimaan Pajak Pertambahan Nilai. Surabaya: Universitas Wijaya Putra.

Widarjono, Agus. (2013). Ekonometrika Pengantar Dan Aplikasinya Disertai Panduan Eviews Edisi 4, Jakarta: UPP STIM YKPN. 